principles connected with the second law of thermodynamics which now form part of our classical knowledge of gas reactions; in this connexion he took out a patent for the synthesis of ammonia which anticipated the Haber process, now so widely used.

Le Chatelier extended the work of Vicat, a friend of his grandfather, on hydraulic cements and was the first to apply petrological methods to the study of this subject; he thus identified several components of Portland cement, and his researches in this con. nexion still form the framework of our knowledge of cements and mortars. He was a pioneer in the application of heat dilatation, electrical conductivity and etching methods to the study of metals and their alloys.

In this brief notice it is impossible to give any adequate account of the vast field covered by $\mathrm{Le}$ Chatelier in the course of his original work; some mention should be made, however, of his literary activities. In 1899 he published a French translation of the papers of Willard Gibbs, with the work of whom his own was so closely interwoven, and he founded the Revue de Métallurgie in 1904. $\mathrm{He}$ published a series of lectures on carbon in 1908 and, with the collaboration of his daughter, Madame Jean Royer, produced in 1925 a book of more general appeal entitled "Science et Industrie". These two books reveal Le Chatelier as he was known to his friends-a profound and original thinker and a highminded and patriotic Frenchman with a deep sense of humour. His reminiscences of his old friends were many and usually combined wisdom and jest. Thus he recalled that Sainte-Claire Deville was a discursive lecturer who furnished his students with little likely to be of service in the approaching examinations. He likened the chemical affinity between sulphuric acid and potash to that existing between a dog and a bone; the dog has an affinity for the bone but it may be equally claimed that the bone has an affinity for the dog and the two mutually absorb each other to form one single entity. The only difference lies in the fact that the dog has personal feelings which are absent in the bone; but how can one say which is the more noble, the acid or the alkali? In such a manner Sainte-Claire Deville expressed his antipathy for so-called scientific theories in which empty words often stand for nonexistent ideas, the term reciprocal affinity serving merely as a vague mode of recalling an experimental fact.

Le Chatelier was a man of fine presence and of courtly manner; he was a brilliant talker and, although advancing years brought deafness, his personal charm always remained. With his death we lose one of the great figures of the scientific France of last century.

WM. J. POPE.

\section{Mr. Sherard O. Cowper-Coles}

THE name of Sherard Cowper-Coles is closely linked to the progress which has been made in numerous branches of electrodeposition work during the last half-century. Born in 1867, his first patent was brought out while he was still a minor, although this had no connexion with electrodeposition; thereafter, there has scarcely been a year when his name has not appeared in the index to the Patent Journal.

Cowper-Coles's life was largely devoted to work in electrodeposition problems, his speciality being processes of electro-forming and applications of electrolysis which were rather outside the sphere of electroplating. If processes which are connected with the decoration and protection of metal surfaces interested him less, it is nevertheless a curious fact that what may possibly be considered his most important contribution from the industrial point of view was a method of protecting steel which is very widely practised to-day, and to which he gave his name-sherardizing. This process consists in the production of a zine coating on ferrous articles, not by electrolysis but by cementation; later, it was progressively improved and now finds considerable application.

Among the many problems which interested Cowper-Coles were the electrodeposition of rubber, deposition on glass, sound recording, needle sharpening, production of white lead by electrolysis, transparent paper, sound-proof ventilation, while he also carried out some work on the smoke abatement problem.

For many years, Cowper-Coles worked in a private laboratory, which he built at Sunbury-on-Thames. Here, favoured visitors would be shown over a most fascinating and unique collection comprising ex. amples of almost every aspect of applied electrodeposition, from electrolytic copper gramophone records to electrodeposited iron tubes of giant size. Most of these exhibits had been produced by CowperColes during his lifetime, and some of them were shown at the Electrodeposition Exhibition held last year by the Electrodepositors' Technical Society at the Science Museum.

During the latter part of his life, Cowper-Coles devoted his efforts to the production of sheets by direct electrodeposition processes. He had a considerable financial as well as scientific genius, and a number of companies were formed to exploit his processes. He published a large number of papers in the proceedings of numerous societies and institu. tions. A man of considerable personal charm of manner, his courtliness was reminiscent of an age long passed. The niche which he filled in the world of electrodeposition was truly unique.

S. WernICK.

We regret to announce the following deaths :

Sir George Hampson, Bt., formerly assistant keeper in the Natural History Museum, known for his work in entomology, on October 15, aged seventysix years.

Prof. Alexander Larmor, formerly McCrea professor of natural philosophy in the Magee University College, Londonderry, on October 12.

Prof. Pietro R. Pirotta, formerly professor of botany in the University of Rome, on August 4, aged eighty-three years. 